\title{
Inhibiting Factors for Implementing Family Hope Program Policies in Bone-Bone District, North Luwu Regency
}

\author{
Zainuddin Mustapa ${ }^{1}$, Andi Rasyid Pananrangi ${ }^{1}$, Hasmini $^{1}$, Nurkaidah $^{1}$ \\ Corresponding Email: h.zainuddinmustapa@gmail.com \\ ${ }^{1}$ Public Administration Science, University of Bosowa, Indonesia \\ Received: December 5, 2021 \\ Received in Revised: December 29, \\ Accepted: January 12, 2022 \\ 2021
}

\begin{abstract}
This study aims to determine and analyse what factors hinder efforts to improve community welfare in Bone-Bone sub-district, North Luwu district. This study uses a qualitative method. The data was collected by means of observation, interviews, online data searching and documentation. The results showed that the factor that hindered efforts to improve community welfare in Bone-Bone District, North Luwu Regency, namely the implementation of socialization at the sub-district and village levels was very low. The sub-district PKH Implementing Unit Secretariat office still uses the sub-district office space. Appointment of PKH implementation staff in the form of sub-district coordinators, assistant staff and computer operators is entirely the responsibility of the Ministry of Social Affairs without involving the local government. There are no incentives or operational funds for facilitators in the field, making it difficult for facilitators to be present at all times in $\mathrm{PKH}$ recipient communities. The factors that support PKH activities are the availability of assistants and operators at the subdistrict level. There are general guidelines for implementing PKH activities. The existence of standard operating procedures (SOP).
\end{abstract}

Keywords: Policy implementation, Family Hope Program, Poverty

\section{Introduction}

Development is a positive activity, so it is desired by all groups because it is related to change or improvement (Bellu 2011). Development is defined as an effort to make changes in people's lives whose ultimate goal is to improve people's welfare. Equity in the distribution of wealth and the achievement of dignity for all is a priority target for development efforts, as stated by Astro Ulakis (2013).

Efforts to improve people's welfare are the goals of the Indonesian people as stated in the preamble to the 1945 Constitution. According to Suharto (2010), community welfare development is all strategies and activities carried out by the government, business world, and civil society to improve the quality of human life through policies and programs for social services, social healing, social protection and community empowerment.

The main goal of improving people's welfare is poverty alleviation. Although improving the welfare of the community is made for a very broad public need, the main targets in this effort are the people in need, namely the poor, children and women victims of violence, street children, child workers, and people with different abilities (disabled).

A policy problem or often referred to as an implementation gap is a situation where in the policy formulation process there is a possible difference between what is planned by the policy maker and what happens as a result or achievement of the implementation of the policy. This 
is partly because the policy implementation process is often influenced by many interests and expectations, especially the perception of the environment in which the policy is implemented.

In realizing a public policy product that aims to realize the welfare of the community, it certainly cannot be separated from various problems. Part of the problem lies not only in the national political will, but also in the implementation of the policy itself through actions rather than implementers as policy makers in the form of the national political will (political action). This is important, considering that the Indonesian nation is a pluralistic society.

Policy can be interpreted more as a process of interaction between the state and the people (Parsons, 2008). Public policy is a policy made with the public sphere, which is a shared scope. This illustrates that the public sphere requires interaction between the state and its citizens in making decisions, one of which is related to social problems that exist in society.

According to data from the Central Statistics Agency (BPS) the poverty rate in North Luwu district in 2018 was 11.25 percent. This shows that the percentage of poor people in North Luwu district is still high. The reduction in the poverty rate of the North Luwu district only decreased by 0.48 percent compared to the previous year, namely in 2019 , which was at 10.77 percent, therefore the North Luwu district government through the relevant offices carried out a comprehensive evaluation of the poverty alleviation program.

In the results of a pre-research conducted by researchers in the Bone-Bone sub-district, North Luwu district on September 7, 2020, it was found that various strategies were carried out by the government related to improving people's welfare. The poverty reduction strategy that has been implemented by the North Luwu district government is to increase the productivity/capacity of the poor through various empowerment programs such as increasing the purchasing power of the poor through controlling inflation, increasing subsidies and social assistance, increasing access to basic services such as education, health, water. clean and other infrastructure, empowering Micro, Small and Medium Enterprises (MSMEs), controlling the population through family planning programs $(\mathrm{KB})$ and other related programs.

\section{Literature Review}

\section{Public Policy}

According to Wojowasito as quoted by Suandi (2010) that public policy consists of two words, namely policy which is a translation of the English word policy which means politics, tactics and wisdom, and public can be interpreted as general, people, society, public, and state or government.

Harold D. Laswell and Abraham Kaplan in Suwitri (2008) define policy as a program to achieve goals, values and directed practices. Policy can also be interpreted as a series of actions proposed by a person, group or government in a certain environment by showing the obstacles and opportunities for the implementation of a proposed policy to achieve certain goals, Carl J. Friedrich in Suwitri (2008).

One part of public policy is making policies or policy formulations. According to Woll in Anggara (2014) that policy formulation is the development of a mechanism to solve public problems. In this process, justification is made to choose a policy that is considered the best.

There are several stages in the preparation of a policy according to Islamy in Anggara (2014), namely; a) Formulation of public policy; b) Preparation of the government's agenda; c) Formulation of public policy proposals; d) Ratification of public policies; e) Implementation of public policies; and f) Assessment of public policy. 
Meanwhile, there are factors that influence in formulating a policy according to $\mathrm{F}$. van Waarden in Anggara (2014). The factors include: a) Political factors; b) Economic or financial factors; c) Administrative or organizational factors; d) Technological factors; e) Social, cultural, and religious factors; and e) Defense and security factors.

\section{Public Policy Implementation}

According to Van Meter and Van Horn (in Budi Winarno, 2008) define the implementation of public policy as actions in previous decisions. These actions include efforts to turn decisions into operational actions within a certain period of time as well as in the context of continuing efforts to achieve large and small changes determined by policy decisions made by public organizations that are directed to achieve the goals that have been set.

The meaning of implementation according to Daniel A. Mazmanian and Paul Sabatier (1979) as quoted in the book Solichin Abdul Wahab (2008), says that: Implementation is understanding what actually happens after a program is declared valid or formulated is the focus of attention on policy implementation, namely events events and activities that arise after the ratification of state policy guidelines which include both efforts to administer them and to cause real consequences/impacts on society or events.

Implementation is a process to turn policy formulations into policy actions in order to realize the desired final results. The policies in this study also mean how the government's steps in responding to the choices of actions taken by the government can: (a) the policies taken can run continuously; (b) can be implemented properly.

\section{Supporting and Inhibiting Factors in Policy Implementation}

The success of policy implementation will be determined by many supporting and inhibiting factors involved in policy implementation. In Edwards III's view, policy implementation is influenced by four factors, namely (1) communication, (2) resources, (3) disposition, and (4) bureaucratic structure. The four factors are also interrelated with each other (Edward III, George C: 1984). Communication of a program can only be carried out properly if it is clear to the implementers. This concerns the process of delivering information, clarity of information and consistency of information submitted.

Resources, including four components, namely sufficient staff (number and quality), information needed for decision making, sufficient authority to carry out tasks or responsibilities and facilities needed in implementation. The disposition or attitude of the implementer is the implementer's commitment to the program. The bureaucratic structure is based on standard operating procedures that regulate work flow and policy implementation

\section{Methods}

This study uses a qualitative method because it is carried out in natural conditions. Sugiyono (2013) suggests that qualitative research methods are qualitative research methods are research methods used to examine the condition of natural objects, where the researcher is the key instrument, data collection techniques are carried out by triangulation (combined), data analysis is inductive, and qualitative research results emphasize more than generalization.

This research was conducted in November-December 2020. The research location was conducted in Bone-Bone District, North Luwu Regency. This research begins with the preparation of research proposals by conducting pre-research activities which include literature searches, print/electronic media, both theoretical literature and related documents. 


\section{Results and Discussion}

After knowing the efforts of the Bone-Bone District government, North Luwu Regency in improving the welfare of the community, the next researcher wanted to know what are the factors that hinder efforts to improve community welfare in Bone-Bone District, North Luwu Regency.

To find out the factors that hinder efforts to improve community welfare in Bone-Bone District, North Luwu Regency, the researcher refers to the top-down perspective implementation model developed by George C. Edward III with the following variables: 1) Communication, 2) Resources (Resources), 3) Bureaucratic structure (Bureaucratic structure). The data - the data obtained in the field as follows:

\section{Communication}

Communication is needed so that decision makers and implementers will be more consistent in implementing every policy that will be implemented in the community. In the communication variable, there are three indicators that can be used to measure the success of a communication, namely transmission, clarity and consistency.

\section{Transmission}

Transmission is the distribution of good communication between the leadership to staff or to the community so that there is no misunderstanding because it has gone through several levels of bureaucracy. The form of transmission here is a socialization or meeting of implementing PKH activities from the Bone-Bone District to the village and community.

From the results of this study, it was found that there was socialization carried out by the subdistrict which is in charge of the PKH section of the welfare and cleanliness of the Bone-Bone District, the sub-district coordinator and village assistants, but the community did not respond or respond well to the PKH program so that some people did not complete the PKH program. the file.

\section{Clarity}

The clarity of the communication referred to in this study is related to the communication received by the implementers of the policy, it must be clear so that it is not confusing in providing information to the public in carrying out their duties. In this study, the clarity of the message conveyed by the communicators or the delivery of the message.

Based on the results of the study, it was found that there was clarity from the facilitators to the community receiving PKH assistance, such as some people who did not understand the PKH program, but village assistants always accompanied and explained the purpose and purpose of PKH so that the community finally understood themselves about the obligations that must be carried out every time. moment.

\section{Consistency}

Submission of communication to policy implementation must be consistent and clear or not changing, so that policy implementers do not misinterpret the policies that have been made. The consistency indicator shows the consistency of the sub-district coordinator and village assistant to the PKH recipient community.

\section{Resources}

The implementation of the implementation that lacks resources will tend to be less effective, while the sub-indicators of the resources that support the implementation of PKH are staff, information, authority and facilities. 


\section{Staff}

The success of the PKH program cannot be separated from the support from the implementing staff in PKH activities. The implementing staff for PKH activities at the sub-district level is the sub-district PKH coordinator, assistant staff, these staff are recruited directly by the Ministry of Social Affairs on-line.

The number of support staff for implementing PKH in Bone-Bone District is 4 people, consisting of $1 \mathrm{PKH}$ Subdistrict Coordinator as well as village assistants, 3 village assistants.

\section{Information}

The form of information in this research is the existence of guidelines or technical instructions that are owned in the implementation of activities. Guidelines or technical instructions used in $\mathrm{PKH}$ activities are general guidelines for PKH implementation issued by the Directorate General of Social Protection and Security, Ministry of Social Affairs of the Republic of Indonesia. These guidelines serve as information material for the sub-district welfare and hygiene section, the sub-district coordinator and village assistants, wards/villages and the community. The Bone-Bone District, the District Coordinator and Village Facilitators in implementing PKH activities in the field refer to the general guidelines issued by the Ministry of Social Affairs of the Republic of Indonesia.

\section{Authority}

In the implementation of PKH activities, authority is an absolute must so that the implementation of PKH can run according to the goals that have been determined. The authority discussed in this study is the authority of assistant staff in verifying PKH recipients. In accordance with the general guidelines for implementing $\mathrm{PKH}$, one of the tasks of the assistant staff is to verify that it becomes the basis for the distribution of assistance that will be received by PKH participants. Based on the verification results, the number of PKH recipients in Bone-Bone District, North Luwu Regency, was 1,219 families.

\section{Facility}

In order to support the implementation of all $\mathrm{PKH}$ administration in the regions, the Bone-Bone District is obliged to provide and facilitate the existence of a PKH Implementing Unit (UPPKH) secretariat. The results showed that the UPPKH secretariat in Bone-Bone District was located at the Bone-Bone District Office.

\section{Bureaucratic Structure}

There are two characteristics that can encourage the performance of the bureaucratic structure to a better direction, namely: implementing Standard Operating Procedures (SOPs) and implementing Fragmentation.

\section{Standard Operating Procedures (SOPs)}

SOPs are routine activities that allow employees to carry out daily activities according to the standards set or required by the residents. In the implementation of PKH activities the Standard Operating Procedures (SOPs) used have been determined from the central government, these SOPs are used in order to set targets, verification, payments and sanctions for PKH participants. The flow of PKH implementation in the regions.

\section{Fragmentation}

In order for the implementation of PKH activities to run smoothly, it is necessary to divide tasks and responsibilities among existing work units. The division of tasks and responsibilities 
is carried out based on the organizational structure that has been made, the aim is that the duties and functions of an organization can be divided evenly among all employees.

Based on the results of research in the field, it shows that the formation of an organizational structure at the sub-district level has been made in the form of a decree from the Social Service of North Luwu Regency and the organizational structure has known the duties and functions of each.

\section{Communication}

Every policy that will be implemented can be channeled to the right people through communication that must be stated clearly, precisely, and consistently.

\section{Transmission}

Communication shows the process of interaction of message delivery through a mediator, the communication factor for implementation is the clarity and content of the message to be fully fulfilled by the recipient of the message or program. In communication, the obstacle in implementing the family of hope program in Bone-Bone District is transmission.

Based on the results of the study that the transmission process went well, because of the socialization carried out by the sub-district in charge of the PKH section of the welfare and cleanliness of the Bone-Bone District, the sub-district coordinator and village assistants, however, the community did not respond or respond well to the PKH program so that some people do not complete the file. So the solution that will be carried out for future improvements is to increase the number of outreach activities at the sub-district or sub-district/village level and involve all existing community groups and increase the budget for the implementation of PKH activities.

\section{Clarity}

Clarity is one of the factors so that the implementation can be well received, if the message conveyed is very clear then it does not make a misinterpretation of a message.

In relation to the implementation of $\mathrm{PKH}$ activities, the assistants in conveying messages to the community regarding the obligations and rights of $\mathrm{PKH}$ participants have been clearly accepted by the community.

It was proven that one of the PKH recipients had a clear understanding of where to go if their family got sick, although at first they still faced various problems, but after being explained and accompanied, the PKH recipient participants understood their rights and obligations.

With the presence of assistants who directly deal with the community, the government's policies will be delivered more quickly and effectively.

\section{Consistency}

One of the requirements for effective implementation is that the implementation orders must be consistent and clear. The implementation of arbitrary orders will guide policy implementation, on the other hand inconsistent orders will encourage implementers to take very loose actions in interpreting and implementing policies.

Based on the results of the study, it shows that the implementation of PKH activities that have been running and directions in the form of rights and obligations conveyed to beneficiaries are still guided by the general guidelines of PKH. If there is a change in the guidelines, the subdistrict PKH coordinator will convey it to the assistant staff and the assistant will also directly convey it to the PKH recipient participants. 


\section{Resource}

The number of support staff for implementing PKH in Bone-Bone District is 4 people, consisting of 1 sub-district PKH Coordinator as well as village assistants, 3 village assistants and the number of PKH participants is 1,219 participants spread over 1 sub-district and 10 villages. A separate challenge for facilitators is to be able to attend meetings in the field, while the number of village assistants in the Bone-Bone sub-district is 4 people, one person also serves as the sub-district PKH coordinator and as a village assistant, thus the workload of PKH staff will increase. heavy.

\section{Information}

Information is an important resource in implementing implementation policies. The form of information used in this PKH activity is the general PKH guideline in which the guideline contains what must be done and how to carry out PKH activities.

The information contained in the general guidelines includes the rights and obligations of PKH participants, targeting mechanism, verification mechanism, distribution of assistance, institutions, socialization and evaluation and monitoring. The implementation of $\mathrm{PKH}$ activities in the Bone-Bone sub-district went well, because the implementers were able to provide correct information regarding the rights and obligations of $\mathrm{PKH}$ participants.

In addition, the assistants will conduct direct verification of all PKH recipients, both in health facilities and in educational facilities, regarding the information they receive.

\section{Authority}

The executor of authority from the implementers of PKH activities will streamline the implementation policies that will be applied. Each implementer involved in PKH activities has the authority in stages, such as assistant staff to record and report on the condition of the components of PKH participant families. Meanwhile, the sub-district PKH coordinator is authorized to carry out analysis and recommendations for PKH implementers in their area.

With the authority to verify PKH implementers by assistants and sub-district PKH coordinators, the payments received by PKH participants will be in accordance with the rights and responsibilities assigned to them.

\section{Facility}

Of the resources that hinder the implementation of PKH activities in the Bone-Bone sub-district are facilities. In order to support the implementation of PKH activities, the government is required to provide facilities in the form of a secretariat office and its supporting facilities in the sub-districts.

The results showed that the UPPKH secretariat in Bone-Bone District was located at the BoneBone District Office. With the limited facilities and infrastructure, it makes the implementation of sub-district PKH activities run modestly. The inhibiting factor in these resources is the limited existing facilities and infrastructure, making the implementation of sub-district PKH activities run smoothly.

\section{Organizational Structure}

\section{Standard Operating Procedures (SOPs)}

In the implementation of PKH activities the Standard Operating Procedures (SOPs) used have been determined from the central government, these SOPs are used in order to set targets, verification, payments and sanctions for PKH participants. 
The implementation of target verification carried out by the assistant staff, refers to the SOP that has been determined by the Ministry of Social Affairs. The results of the verification and validation are used as the basis for payments to PKH participants.

\section{Fragmentation}

$\mathrm{PKH}$ is a program from the central government so that it can run well, the involvement of local governments is very necessary for the success of this program. The responsibilities of each stakeholder from the central, provincial and regional levels must be clear so that the implementers can act according to their respective duties and functions or there is no overlapping of main tasks and functions.

Likewise, in the area, the division of tasks and functions must be distinguished between the implementing technical service and the district PKH coordinator, assistant staff and the Subdistrict and Village/Village parties as well as PT. Pos Indonesia can find out their respective duties.

\section{Conclusion}

Factors that hinder efforts to improve community welfare in Bone-Bone District, North Luwu Regency, namely the implementation of socialization at the sub-district and sub-district/village levels is very low. The sub-district PKH Implementing Unit Secretariat office still uses the subdistrict office space. The appointment of PKH implementing staff in the form of District Coordinators, Assistance Personnel and Computer Operators is entirely the responsibility of the Ministry of Social Affairs without involving the Regional Government. There are no incentives or operational funds for facilitators in the field, making it difficult for facilitators to be present at all times in PKH recipient communities. The factors that support PKH activities are the availability of assistants and operators at the sub-district level. There are general guidelines for implementing PKH activities. The existence of Standard Operating Procedures (SOPs).

\section{References}

Anggara, Sahya. (2014). Kebijakan Publik. Bandung : CV Pustaka Setia

Astroulakis, N, (2013), Ethics and International Development: The Development Ethics Paradigm", Journal of Economics and Business, Vol. XVI-2013, No 1, pp. 102.

Bellu, Lorenzo G, (2011). Development and Development Paradigma (Reasoned) Review of Prevailing Vision, Rome Itali: FAO.

Edward III, George C (edited), 1984, Public Policy Implementing, Jai Press Inc, LondonEngland.

Parsons, Wayne. (2008). Public Policy: An Introduction to the Theory and Practice of Policy Analysis (Tri Wibowo Budi Santoso, Penerjemah). Jakarta: Kencana Prenada Media Group.

Suandi, I Wayan. (2010). Eksistensi Kebijakan Publik dan Hukum Dalam Pemerintahan Daerah. Jurnal Ilmiah Fakultas Ilmu Sosial dan Ilmu Politik Universitas Udayana bali. Vol.I No. 01, Tahun 2010.

Sugiyono. (2013). Metode Penelitian Pendidikan Pendekatan Kuantitatif, Kualitatif, dan R\&D. Bandung: Alfabeta.

Suharto, Edi, (2010), Membangun Masyarakat Memberdayakan Rakyat. Bandung: Refika Aditama. 
Suwitri, Sri. (2008). Konsep Dasar Kebijakan Publik. Semarang: Badan Penerbit UNDIP.

Wahab, Wahab, Solichin (2008). Analisis Kebijaksaan dari formulasi ke implementasi kebijaksanaan negara. Jakarta : Bumi Aksara

Winarno B, (2014). Kebijakan Publik : Teori, Proses dan Studi Kasus. Yogyakarta. Caps Publishing. 